\title{
Legemiddelstatistikk og legemiddelepidemiologi - redskap til en bedre helsetjeneste
}

\author{
Marit Andrew \\ Statens helsetilsyn, Oslo \\ Nåværende adresse: Fagdirektør, AllianceUniChem Norge, Sandviksveien 22, 1322 Høvik \\ e-post: m.andrew@alliance-unichem.no
}

Jeg må først takke for invitasjonen til å holde et innlegg ved åpningen av dette viktige symposiet, hvor så mye nordisk kompetanse på legemiddelepidemiologi og legemiddelstatistikk - fra helsetjeneste, forskning og myndigheter - er samlet på ett brett. Jeg har selv gjennom årene erfaring fra alle disse arenaene. De siste årene - og i dag - har jeg myndighetshatten på.

\section{STATENS HELSETILSYN: TILSYN OG RÅDGIVNING}

Først noen ord om Statens helsetilsyn som jeg her er representant for. På engelsk heter vi Norwegian Board of Health, og helsedirektøren i Norge er min sjef.

Mitt ønske er at Helsetilsynet først og fremst skal assosieres med kvalitet. Administrativt sorterer vi under Sosial- og helsedepartementet, og vårt oppdrag er gitt av Stortinget gjennom Tilsynsloven. Helsetilsynets oppgave er å føre tilsyn med all helsetjeneste (virksomheter) og alt helsepersonell. Tilsynet er først og fremst et virkemiddel for å bidra til kvalitet $\mathrm{i}$ helsetjenestene, og er ikke primært for å knipe "syndere". Tilsynet skal kunne tjene til å evaluere helsetjenesten $\mathrm{i}$ forhold til helsepolitiske satsningsområder og prioriteringer. Kvalitet i tjenestene og trygge helsetjenester er noe langt mer enn at de ikke er uforsvarlige.

Helsetilsynet tar ikke bare stilling til om myndighetenes krav er innfridd, vi må også ta stilling til kvalitet og prioriteringer i et ressursmessig perspektiv: hvordan er helsetjenestens resultater i forhold til kvalitet og kapasitet? Er fordelingen rettferdig i forhold til geografisk fordeling og ulike pasientgrupper - og kjønn? Er tjenestene effektive?

Tilsvarende spørsmål må vi også stille når det gjelder legemidler som innsatsfaktor.

Tilstanden kan vi, Helsetilsynet og våre 19 fylkeslegekontorer, si noe om på bakgrunn av egne erfaringer/observasjoner gjennom systematiske tilsyn (eks. sykehushygiene, skolehelsetjeneste, ventelistegaranti) og kartlegginger (eks. korridorsenger, isolatkapasitet, helsepersonellsituasjonen), og kunnskap fra andre kilder. Legemiddelbruk har vi nå et for lite faktagrunnlag om, noe som jeg kommer tilbake til.

Et viktig ledd i arbeidet med overordnet faglig til- syn er den årlige Tilsynsmeldingen. Den vil jeg anbefale dere å lese. Den er kanskje mer spennende enn dere tror! Den ligger på nettet sammen med tilsynsrapporter, regelverk, veiledere, rundskriv og mye annet nyttig stoff.

Rådgivning henger nært sammen med tilsynet. Vi har valgt å skille ut rådgivning som en egen oppgave, både for å understreke denne siden ved tilsynet og for å se nærmere på hvilken særskilt rolle Helsetilsynet og fylkeslegene har med hensyn til rådgivning, $\mathrm{i}$ forhold til andre aktører. Vi utgir retningslinjer, veiledere osv., og bidrar i nasjonale handlingsplaner som for eksempel Nasjonal strategi for kvalitet i helsetjenesten, geriatri, HIV-Aids, psykiatri, eldresatsningen (sammen med fylkesmennene), kvalitetsrådgiverprogrammet for kommunene osv.

Spesielt vil jeg nevne utviklingen av Retningslinjer for retningslinjer i samarbeid med alle sentrale fagmiljøer.

\section{LEGEMIDLER - VIKTIG INNSATSFAKTOR}

Fordi vi mangler kunnskap til å si noe om rikets tilstand når det gjelder legemiddelområdet, har Helsetilsynet tidlig og tydelig gitt Sosial- og helsedepartementet råd om å etablere en reseptbasert legemiddelstatistikk i Norge.

Nest etter helsepersonell er legemidler kanskje den viktigste innsatsfaktoren i helsetjenesten. Legemidler kan forebygge, lindre og kurere sykdom og får en stadig økende betydning. Etter personellkostnader utgjør legemidler den i særklasse største utgiftsposten på helsebudsjettene. Vi bruker legemidler for mer enn 10 milliarder kroner på årsbasis, og kostnadene øker med ca. 3 millioner kroner per dag sammenliknet med året $\mathrm{i}$ forveien. Rundt 7 av de 10 milliardene dekkes over offentlige budsjetter, gjennom blåreseptordningen og gratis legemidler i sykehus. Til sammenligning er de offentlige kostnadene til primærhelsetjenesten snaue 6 milliarder, mens drift av sykehus beløper seg til 28 milliarder kroner årlig. Ikke rart at politikere og helsemyndighetene er opptatt av både legemiddelpriser og legemiddelbruk. 


\section{HeLHETLIG PERSPEKTIV}

En viktig utfordring på legemiddelområdet er å bruke legemidlene slik at de gir optimal nytte for pengene, både for individ og samfunn. Bruk av penger til legemidler må tåle sammenligning med alternativ bruk av ressursene. Skal vi for eksempel bruke penger på dagens Alzheimer-legemidler eller bruke mer ressurser til omsorg for Alzheimerpasienter, eller skal vi bruke mer ressurser til en annen prioritert pasientgruppe? Med andre ord: rasjonell forskrivning og bruk av legemidler må ses $i$ et helhetlig helse- og samfunnsperspektiv.

Det er i dag et stort misforhold mellom den kunnskap som ligger til grunn for godkjenning av et legemiddel og den kunnskap vi har om forhold av betydning for nytten $i$ allmenn bruk. Vi vet derfor mer om halveringstid enn om compliance, mer om distribusjonsvolum enn om "outcome".

\section{LEGEMIDDELSTATISTIKK}

Blodtrykksmedisin og lipidsenkende midler er eksempler på legemidler hvor milliardbeløp brukes for å redusere risiko for å oppleve en fremtidig hendelse, for eksempel hjerneslag eller hjerteinfarkt. Risiko er et vanskelig begrep å forholde seg til både for lege og pasient. Vi kan redusere risiko "in absurdum". Legemiddelbruk rettet mot risikofaktorerer er blitt vår tids farsott, det norske ordet for epidemi. For å få kunnskap om denne moderne "epidemien", må vi bruke epidemiologiens verktøy. Herunder hører en god legemiddelstatistikk.

Bedre og mer kunnskap kan gi oss bedre helsetjenester innenfor de ressurser vi rår over. Det politiske ansvaret her handler mye om å prioritere. Dette betyr samtidig å kunne si nei og å sette grenser.

Legemiddelstatistikk er et redskap som er nyttig over et bredt spekter - fra rene myndighetsbehov, som å følge med i prisdannelser og konkurranseforhold i legemiddelmarkedet for ikke å betale mer enn nødvendig, via planlegging, simulering og oppfølging av effekten av tiltak, tilsyn og kontroll, kvalitetssikring i helsetjenesten, epidemiologisk og klinisk forskning og helt ut til industriens markedsføringsstudier og markedsanalyser.

I Norge har vi hatt en god og allmennt tilgjengelig grossiststatistikk siden på midten av 70-tallet. Da var vi et foregangsland. I mellomtiden har legemiddelområdet vokst og blitt mer komplekst. Grossiststatistikken er ikke lenger tilstrekkelig til å gi oss svar. Vi trenger mer tidsmessige verktøy og kompetanse til å bruke dem. I Norge ble det i 1999 fattet vedtak om at det skal etableres en offentlig og reseptbasert legemiddelstatistikk, slik vi ser for eksempel i Danmark og Finland. Men først må mange hindere forseres, hvorav personvernet og record linkage/ registerkobling er to, før vi er i mål. At statistikken skal være offentlig, er et viktig prinsipp for Helsetilsynet. Det pålegger samtidig eieren, som (foreløpig) er departementet, en plikt til å vurdere nøye de ulike muligheter en slik statistikk gir, og hvordan tilgjengelighet kan ivaretas, slik at den kan utnyttes til å frembringe ny og nødvendig kunnskap om legemidlers nytte og begrensninger og god ressursbruk. Det inkluderer både hvem som skal få tilgang, til hva, hvor detaljert og faktisk også pris. Videre må det finnes kompetanse og ressurser til å bruke statistikken.

Farmasøyt og forsker Kari Furu er nylig tilsatt som rådgiver i departementet for å samordne planleggingen av en slik reseptstatistikk i Norge.

Epidemiologisk sett er hvert av de nordiske land små. Men til sammen har vi et befolkningsgrunnlag på mer enn 20 millioner. Det er verdifullt med slike symposier som dette, hvor nordiske naboer kan dele erfaringer og synliggjøre hvordan en god statistikk kan gi nytte for forskning, myndigheter, helsetjenesten og befolkningen. Mitt framtidsønske er derfor at vi også kan utvikle det nordiske samarbeidet rundt reseptstatistikk, både på myndighets- og forskningsnivå. 